\title{
DEVELOPMENT OF TECHNIQUE AND PROGRAM FOR ANALYSIS OF OPTIONS FOR TRANSITION TO A CLOSED HOT-WATER SUPPLY SCHEME FOR HEAT SUPPLY SYSTEMS
}

\author{
F.N. Gazizov, I.G. Akhmetova \\ ${ }^{1}$ LLC “Neva Energy", St. Petersburg, Russia \\ ${ }^{2}$ Kazan State Power Engineering University
}

\begin{abstract}
The article describes the prerequisites for development of methodology for integrated assessment of options for transition to a closed hot-water supply scheme. For analysis of promising options for transition to a closed system of hot water supply, criteria have been proposed that influence the choice of possible solutions. Block diagrams of boundary conditions and independent variables were created. A pyramid of indicators which affect the operating costs of heating system over 25 years of its operation was formulated. A method and a program for selecting the optimal transition scheme to a closed hot-water supply system with calculation of weighting factors have been developed.
\end{abstract}

Key words: heat networks, hot water supply, heat supply system, method of selecting the optimal solution, weighting factors.

For citation: Gazizov FN, Akhmetova IG. Development of technique and program for analysis of options for transition to a closed hot-water supply scheme for heat supply systems. Power engineering: research, equipment, technology. 2019; 21(5-6):126-134. (In Russ). doi:10.30724/1998-9903-2019-21-3-126-134.

\section{РАЗРАБОТКА МЕТОДИКИ И ПРОГРАММЫ АНАЛИЗА ВАРИАНТОВ ПЕРЕВОДА НА ЗАКРЫТУЮ СХЕМУ ГВС СИСТЕМЫ ТЕПЛОСНАБЖЕНИЯ}

\author{
Ф. Н. Газизов ${ }^{1}$, И.Г. Ахметова ${ }^{2}$ \\ ${ }^{1}$ ООО «Невская Энергетика», Санкт-Петербург, Россия \\ ${ }^{2}$ ФГБОУ ВО «КГЭУ», Казань, Россия
}

\begin{abstract}
Резюме: в статье рассмотрены предпосылки разработки методики укрупненной оценки вариантов перевода на закрытую схему ГВС. Для анализа перспективных вариантов перехода на закрытую систему ГВС предложены критерии, влияющие на выбор возможных решений. Составлены блок-схемы граничных условий и независимых переменных. Сформулирована пирамида показателей, влияющих на эксплуатационные затраты системы теплоснабжения за 25 лет ее применения. Разработана методика и программа выбора оптимальной схемы перехода на закрытую систему ГВС с расчетом весовых коэффиииентов.
\end{abstract}

Ключевые слова: тепловые сети, горячее водоснабжение, система теплоснабжения, методика выбора оптимального решения, весовые коэффициенты. 


\section{Introduction}

From July 27, 2010 the Federal Law No. 190 "On Heat Supply" (hereinafter FZ-190) entered into force, so most heat supply organizations and local self-government bodies were faced with the issue of transition of subscribers connected to hot water supply (HWS) through an open circuit to a closed circuit of HWS preparation [1,2]. This obligation is enshrined in paragraph 9 of Article 29 of FZ-190. Taking into account the fact that more than half of the heat supply systems operating in Russia today are open, the question of choosing the most appropriate method for switching to a closed DHW preparation scheme is quite acute [3 - 6].

To date, there is no approved methodology for an integrated assessment of options for transition to a closed hot water supply scheme at the scale of settlements/cities. The only possible method for comparing options and assessing the cost of measures to organize a closed hot water supply system is the technical and economic study of each option for a given city. This work in itself requires significant costs, and therefore, local authorities are not ready to carry it out. As a result, the solutions included in the designed heat supply schemes are either not sufficiently substantiated, or there is no justification for the decisions taken.

Development of choice criteria for options of transition to closed HWS system

To analyze perspective options of transition to closed HWS scheme it is necessary to evaluate the criteria that affect the choice of each of the possible solutions [7]. Table 1 presents the main criteria and characteristic that they affect.

Table 1

The main criteria for choosing an option for transition to a closed HWS system

\begin{tabular}{|c|c|c|}
\hline Criterion & Characteristic & Note \\
\hline $\begin{array}{l}\text { Heating season degree-day } \\
\text { (HSDD) }\end{array}$ & $\begin{array}{l}\text { Heat losses from the surface } \\
\text { of the pipeline/hydraulic } \\
\text { losses in the networks }\end{array}$ & $\begin{array}{l}\text { The four-pipe system in } \\
\text { comparison with the two-pipe one } \\
\text { has a larger surface of heat } \\
\text { exchange with the environment } \\
\text { and a larger total length of the } \\
\text { heating networks. }\end{array}$ \\
\hline Source type & CHPP/boiler house & $\begin{array}{l}\text { For a CHPP, the use of a four- } \\
\text { pipe system is economically } \\
\text { unreasonable. }\end{array}$ \\
\hline $\begin{array}{l}\text { Availability of space for } \\
\text { additional equipment at } \\
\text { consumer }\end{array}$ & $\begin{array}{l}\text { Dimensions of basement of } \\
\text { residential buildings }\end{array}$ & $\begin{array}{l}\text { In case of lack of free space or } \\
\text { inability to access it, installation } \\
\text { of individual heating unit (IHU) } \\
\text { is not possible. }\end{array}$ \\
\hline Population density & $\begin{array}{l}\text { The specific heat load of the } \\
\text { region }\left(\mathrm{Gcal} / \mathrm{km}^{2}\right)\end{array}$ & $\begin{array}{l}\text { At low population density, } \\
\text { options with a developed heating } \\
\text { network (four-pipe system or } \\
\text { central heating system) are more } \\
\text { expensive. }\end{array}$ \\
\hline $\begin{array}{l}\text { Capacity of cold water supply } \\
\text { (CWS) networks }\end{array}$ & $\begin{array}{l}\text { Hydraulic losses in the } \\
\text { networks }\end{array}$ & $\begin{array}{l}\text { When switching to IHU/central } \\
\text { heat supply station (CHSS) } \\
\text { options, the load on CWS } \\
\text { networks significantly increases. } \\
\text { In this case, for HWS, either a } \\
\text { separate branch with cold water is } \\
\text { required, or the option of } \\
\text { connecting via a four-pipe system } \\
\text { becomes appropriate. }\end{array}$ \\
\hline
\end{tabular}


Continuation of the table

\begin{tabular}{|c|c|c|}
\hline $\begin{array}{l}\text { The presence of HWS cut on } \\
\text { the temperature chart }\end{array}$ & $\begin{array}{l}\text { Temperature chart of the } \\
\text { heating network }\end{array}$ & $\begin{array}{l}\text { An additional factor in the } \\
\text { transition to the four-pipe system, } \\
\text { where the temperature cut can be } \\
\text { abandoned. }\end{array}$ \\
\hline $\begin{array}{l}\text { The real heat load of the } \\
\text { district }\end{array}$ & $\begin{array}{l}\text { The presence or absence of a } \\
\text { reserve capacity of the heating } \\
\text { network }\end{array}$ & $\begin{array}{l}\text { The increase in network water } \\
\text { consumption for CHSS/IHU } \\
\text { options compared with the four- } \\
\text { pipe system and, as a result, the } \\
\text { need for new networks. }\end{array}$ \\
\hline $\begin{array}{l}\text { The ratio of peak load for } \\
\text { heating and hot water supply }\end{array}$ & $\begin{array}{l}\text { Heat losses from the surface } \\
\text { of the pipeline/hydraulic } \\
\text { losses in the networks }\end{array}$ & $\begin{array}{l}\text { The four-pipe system in } \\
\text { comparison with the two-pipe one } \\
\text { has a larger surface of heat } \\
\text { exchange with the environment } \\
\text { and a larger total length of the } \\
\text { heating networks. }\end{array}$ \\
\hline $\begin{array}{l}\text { Soil type and the possibility of } \\
\text { work performance }\end{array}$ & $\begin{array}{l}\text { The density of urban } \\
\text { development, improvement of } \\
\text { the district, access to } \\
\text { communications, etc. }\end{array}$ & $\begin{array}{l}\text { The cost of pipeline laying } \\
\text { directly depends on the } \\
\text { complexity of construction and } \\
\text { installation works. }\end{array}$ \\
\hline $\begin{array}{l}\text { The existing connection } \\
\text { schemes }\end{array}$ & $\begin{array}{l}\text { The ratio of the existing load } \\
\text { connection schemes for HWS: } \\
\text { open system/IHU/CHSS/four- } \\
\text { pipe system. }\end{array}$ & $\begin{array}{l}\text { Availability at the heat supply } \\
\text { source of the appropriate } \\
\text { equipment and experience of } \\
\text { working with it of the operating } \\
\text { organization. }\end{array}$ \\
\hline Operation costs & $\begin{array}{l}\text { Service life of pipelines and } \\
\text { main equipment. }\end{array}$ & $\begin{array}{l}\text { The four-pipe system, unlike } \\
\text { CHSS/IHU, does not require } \\
\text { regular technical inspection and } \\
\text { replacement of the main } \\
\text { equipment. }\end{array}$ \\
\hline
\end{tabular}

Table 1 considers exclusively basic assessing criteria of transitioning options to a closed HWS system. In a real project, this list can be reduced or expanded depending on the current situation in the considered project. Nevertheless, it is appropriate to divide the proposed criteria into two categories:

- Boundary conditions (according to the type of logical variables "true/false");

- Independent variables (the value of which will vary in different projects and will be converted into natural or monetary equivalents).

\section{Drawing up a block diagram of boundary conditions and independent variables}

The positions 2, 3, 6, and 10 of the basic criteria shown in Table 1 can be proposed as boundary conditions. Figure 1 shows an explanatory block diagram for accounting these boundary conditions. 


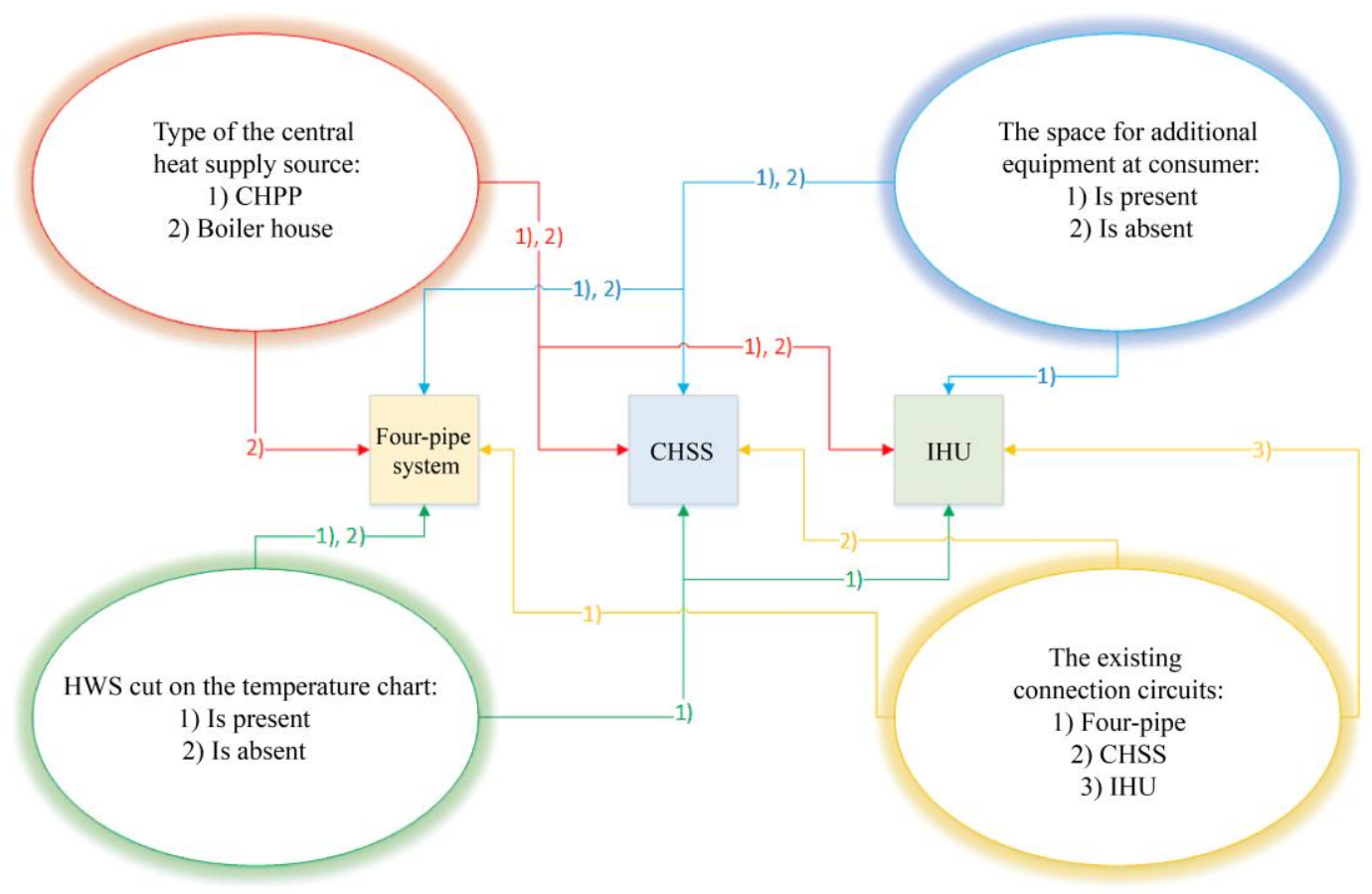

Fig. 1. Block diagram of boundary conditions

The other criteria presented in Table $1(1,4,5,7,8,9,11)$ have a quantitative assessment (toe, $\mathrm{kW} \cdot \mathrm{h}, \mathrm{rub}$.) and are considered as independent variables. Fig. 2 shows an explanatory block diagram for accounting of independent variables data. The considered criteria include: heating season degree-day (HSDD), population density, capacity of cold water supply networks (CWS), real heat load of the district, the ratio of the peak load on heating and hot water supply, soil type, as well as the possibility of work performance and operating costs. These independent variables are presented in the diagram as gray squares and are connected to the indicators they affect.

A significant difference between the criteria of Fig. 2 from the positions shown in Fig. 1 is the presence of a natural and, as a result, cash equivalent, allowing one to quantify the impact of each position on the decision to choose a priority scheme for the district HWS. An important feature of this block diagram is separation of costs for capital investments and annual costs. The second indicator becomes extremely relevant when comparing heat and hydraulic losses, as well as the cost of repair work and replacement of the main equipment. It is further recommended that all economic indicators be added over a period of 25 years. Such an approach will allow a more objective assessment of the options for the CHSS/IHU and the four-pipe system, as it takes into account the nominal life of pipeline equipment, which is 25 years for metal products. In addition, the announced period will include major repairs and replacement of heat exchange equipment for options with installation of heating units according to the type of CHSS/IHU. 


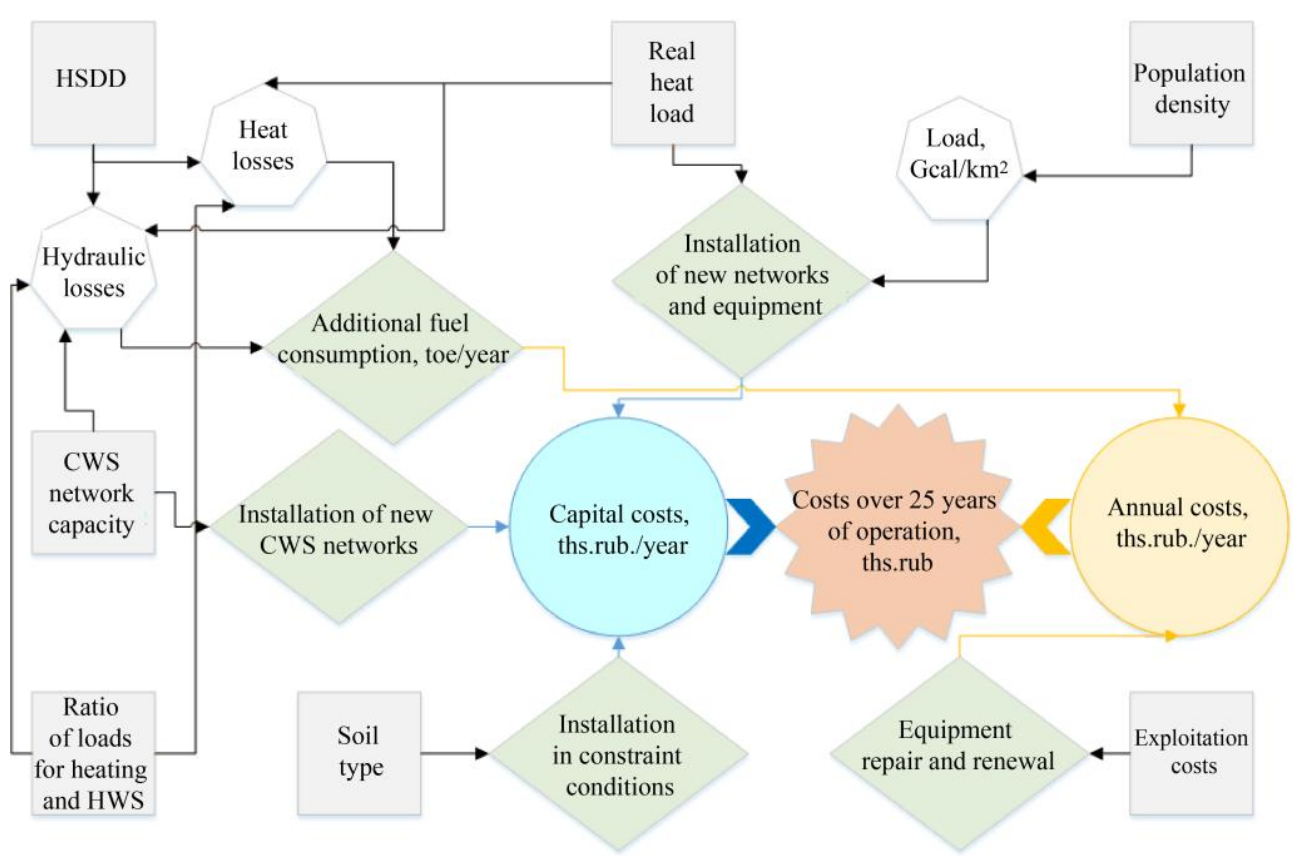

Fig. 2. Block diagram of independent variables

Thus, it is possible to compile an enlarged block diagram for assessing the options for transition to a closed HWS system taking into account the indicators presented in Figs. 1 and 2. Below is the basic calculation scheme in the framework of the developed methodology (Fig. 3).

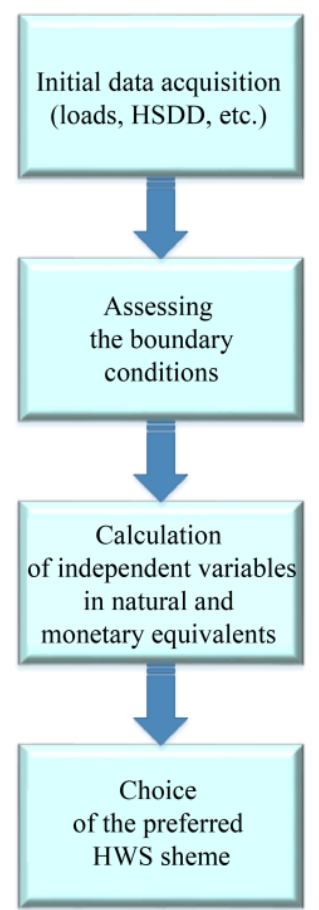

Fig. 3. Basic scheme for choosing the optimal HWS system 


\section{Development of a program for choosing the optimal HWS scheme}

The final indicator for choosing the option of switching to a closed system, as noted in Fig. 2 , are the cash costs over 25 years of operation of a newly introduced or reconstructed heat supply system. However, due to inflation, changes in market prices for equipment and other indicators that affect the final project cost, it is difficult to use accurate quantitative indicators to select the optimal solution. For this reason, the developed methodology is based on the analysis of a variety of relevant feasibility studies for various projects with selection of qualitative weighting factors for each of the criteria.

Based on these assumptions, a pyramid of indicators can be formulated that affects the operating costs of the heat supply system for 25 years of its application. Figure 4 presents this scheme, which is based on indicators that are affected by all 7 previously considered criteria (Fig. 2).

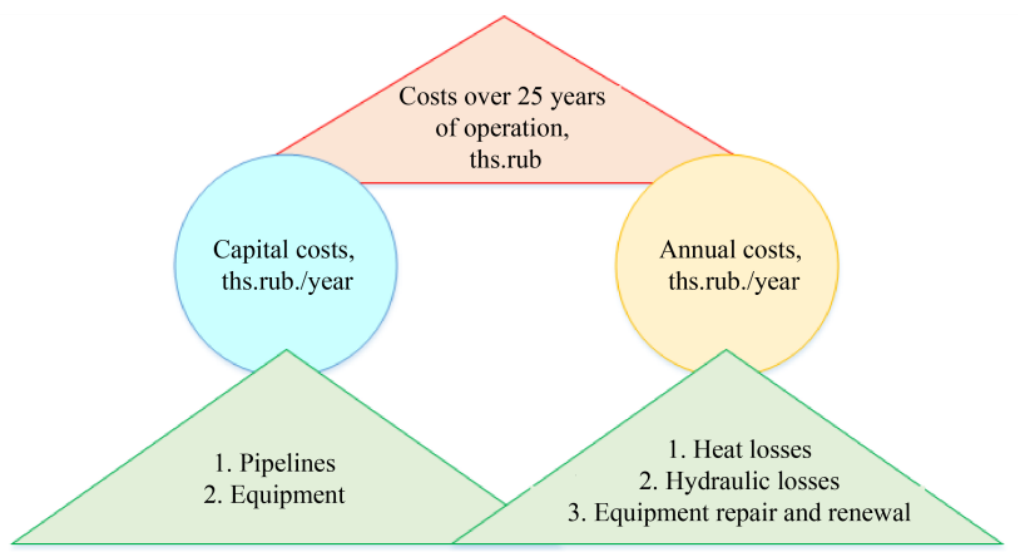

Fig. 4. Pyramid of costs over 25 years of operation

Fig. 4 shows that capital costs include 2 items, while annual costs include 3 items. Figures 5-7 present the interface of the program for choosing the optimal scheme of transition to a closed HWS system with the calculation of weighting factors. Here, a weighting factor equal to 1 approximately corresponds to costs of 100 million rubles.

\begin{tabular}{|c|c|c|c|}
\hline \multicolumn{2}{|l|}{ City } & \multicolumn{2}{|c|}{ Norilsk } \\
\hline \multicolumn{2}{|c|}{ Heat load, Gcal/h } & \multicolumn{2}{|c|}{100} \\
\hline \multicolumn{2}{|l|}{ Heating } & \multicolumn{2}{|c|}{80} \\
\hline \multicolumn{2}{|l|}{ HWS } & \multicolumn{2}{|c|}{20} \\
\hline \multicolumn{2}{|c|}{ Heat consumption, Gcal/year } & \multicolumn{2}{|c|}{500000} \\
\hline \multicolumn{2}{|c|}{ Average network diameter, mm } & \multicolumn{2}{|c|}{80} \\
\hline \multicolumn{4}{|c|}{ Analysis of boundary conditions: } \\
\hline Source & CHPP & \multicolumn{2}{|l|}{ Boiler house } \\
\hline $\begin{array}{l}\text { Place } \\
\text { for equipment }\end{array}$ & Yes & No & \\
\hline Cut & Yes & No & \\
\hline Scheme & 4-pipe & CHSS & $\mathrm{IHU}$ \\
\hline \multicolumn{4}{|c|}{ Input of independent variables } \\
\hline \multicolumn{3}{|l|}{ HSDD } & 6000 \\
\hline \multicolumn{3}{|c|}{ Network length for an option with IHP, km } & 100 \\
\hline \multicolumn{3}{|c|}{ Tariff for electrical energy, rub./kWh } & 4 \\
\hline \multicolumn{3}{|c|}{ Tariff for heat energy, rub./Gcal } & 2000 \\
\hline \multicolumn{3}{|c|}{ Soil type ( 1 for dry, 1.14 for wet) } & 1 \\
\hline
\end{tabular}

Fig. 5. Initial data input 


\begin{tabular}{|c|c|c|c|c|}
\hline \multicolumn{5}{|c|}{ Cost for network laying } \\
\hline Dy, mm & Dry soil to spoil & Dry soil with disposal & Wet soil to spoil & Wet soil with disposal \\
\hline 80 & 16225.7 & 17355.48 & 20801.72 & 22293.53 \\
\hline 100 & 19586.28 & 20833.91 & 24169.26 & 25782.91 \\
\hline 125 & 20981.97 & 22167.25 & 25508.4 & 27116.25 \\
\hline 150 & 22969.73 & 24211.56 & 27553.05 & 33160.9 \\
\hline 200 & 26883.82 & 28418.26 & 31470.69 & 40132.87 \\
\hline 250 & 33121.31 & 35089.88 & 37833.5 & 42735.89 \\
\hline 300 & 36037.88 & 37683.05 & 40680.13 & 49507.08 \\
\hline 350 & 42216.64 & 44354.67 & 46910.79 & 55454.14 \\
\hline 400 & 48161.93 & 50299.96 & 52823.73 & 61783.43 \\
\hline 450 & 54361.8 & 56618.46 & 59029.92 & 67276.8 \\
\hline 500 & 59855.17 & 62111.84 & 64493.78 & \multicolumn{2}{c|}{ The ratio of wet and dry soils } \\
\hline & & &
\end{tabular}

Fig. 6. Intermediate calculations

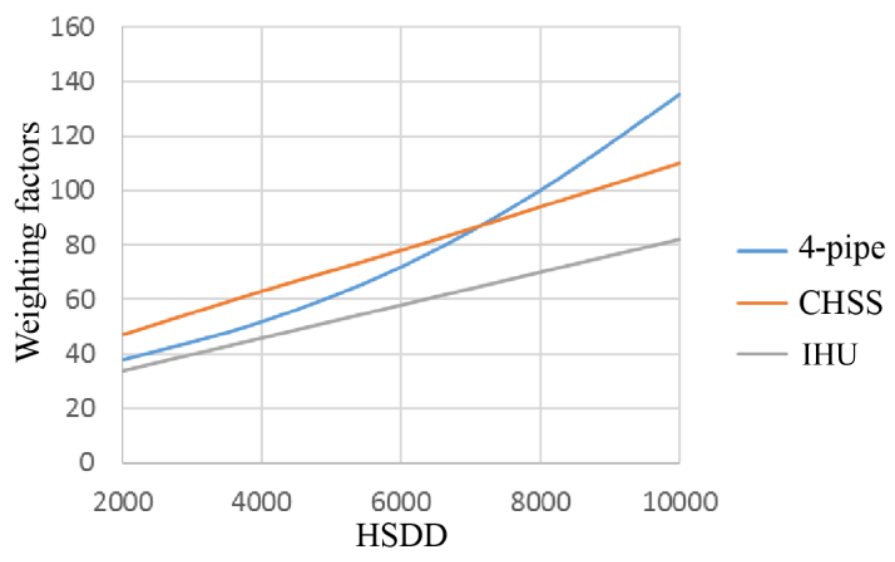

Fig. 7. Calculation results presented in the graphical form

\section{Conclusions}

Based on the results of the analysis, the following conclusions can be drawn:

- The final indicator for choosing the option of switching to a closed system is the cash cost over 25 years of operation of the newly introduced or reconstructed heat supply system. However, due to inflation, changes in market prices for equipment and other indicators that affect the final cost of the project, it is difficult to use accurate quantitative indicators to select the optimal solution.

- It has been established that when implementing a closed HWS system, the material characteristic of networks increases as follows: for $100 \%$ for a four-pipe network (when switching to a closed HWS system using a four-pipe scheme, it is required to lay $100 \%$ of the material characteristic of the pipelines of HWS networks from source to consumers); for $70 \%$ for a network with a central heat supply station (when switching to a closed HWS circuit via a CHSS, it is required to lay about $70 \%$ of the material characteristics of the pipelines of HWS networks from the central heating system to consumers); $0 \%$ for a network with IHU (main networks for HWS are not laid).

- The sharpest increase in heat losses is observed for the variant with a four-pipe system. So for HSDD equal to 9000 , the equality of heat losses for the four-pipe heat network and the system with IHU is noticeable.

- About $55 \%$ of all costs are heat losses, which means that the HSDD indicator will be one of the most important when choosing a reconstruction option.

- The developed methodology proved its applicability when compared to a detailed feasibility study. 


\section{References}

1. Kolesnikov AN, Mitin MA. Analysis of execution of the Federal law 416-FZ on transition to closed HWS systems. New equipment and technologies. Bulletin of DITI 2017; 2: 84 - 92.

2. Puzakov VS. Analiz razrabotki skhem teplosnabzheniya v RF. Vodosnabzhenie i sanitarnaya tekhnika. 2015; 7: 4 - 13. (In Russ).

3. Akhmetova IG, Mukhametova LR. Topical issues of energy efficiency of heat supply organizations. Power engineering: research, equipment, technology.. 2015;

(11-12):108-113.(InRuss.) https://doi.org/10.30724/1998-9903-2015-0-11-12108-113.

4. Savina NV., Artjushevskaja EJ. Actual problems of realization of the federal law № 261 from 23.11.2009 in the Russian Federation in the part of heat supply. Power engineering: research, equipment, technology..2017; 19(3-4):31-40. (In Russ.) https://doi.org/10.30724/1998-9903-2017-19-3-4-3140.

5. Strenadko IM, Rozhkov RYu, Kiyski AV. On problems of open thermal supply networks. Thermal supply news. 2013; 1:34-38.

6. Edeleva OA. The choice of an approach to study the problems of energy sources optimum development in the urban heat supply systems. Power engineering: research, equipment, technology. 2017; 19(5-6):58-68. (In Russ.) https://doi.org/10.30724/1998-9903-201719-5-6-58-68.

7. Zhukov DV, Chicherin SV. Some outcome of Omsk heat transmission pressure tests. Power engineering: research, equipment, technology. 2017; 19(1-2):15-22. (In Russ). https://doi.org/10.30724/1998-9903-201719-1-2-15-22.

8. Tikhomirov SA, Vasilenko AI. Problems of transition to closed thermal supply networks // Don engineering bulletin. 2013; 4(27).

9. Postnikov IV, Stennikov VA. Ensuring of parametric reliability of heat supply systems. Power engineering: research, equipment, technology. 2017; 19(3-4):20-30. (In Russ.) https://doi.org/10.30724/1998-9903-2017-19-3-4-2030 .

10. Mukhametova LR, Akhmetova IG, Akhmetov TR. Evaluating the effectiveness of energy efficiency programs. Problems of energy saving in heating. Power engineering: research, equipment, technology. 2015;(9-10):12-21.(InRuss). https://doi.org/10.30724/1998-9903-2015-0-9-10-1221.

\section{Литература}

1. Колесников А.Н., Митин М.А. Анализ исполнения федерального закона 416-Ф3 о переходе к закрытым системам ГВС // Новая техника и технологии. Вестник ДИТИ. 2017. № 2. C. $84-92$.

2. Пузаков В.С. Анализ разработки схем теплоснабжения В РФ // Водоснабжение и санитарная техника. 2015. №7. С. 4-13.

3. Ахметова И.Г., Мухаметова Л.Р. Актуальные вопросы повышения энергоэффективности теплоснабжающих организаций // Известия высших учебных заведений. ПРОБЛЕМЫ ЭНЕРГЕТИКИ. 2015;№ 11-12. С. 108-113.

4. Савина Н.В., Артюшевская Е.Ю. Актуальные проблемы реализации федерального закона № 261 от 23.11.2009 г. в Российской Федерации в части теплоснабжения. Известия высших учебных заведений. ПРОБЛЕМЫ ЭНЕРГЕТИКИ. 2017; T.19. № 3-4. C. 31-40.

5. Стренадко И. М., Рожков Р. Ю., Кийски А. В. О проблемах открытых систем теплоснабжения // Новости теплоснабжения. 2013. №. 1. С. 34 - 38.

6. Еделева О.А. Выбор методического подхода для решения задачи оптимального развития энергоисточников в теплоснабжающих системах городских территорий. Известия высших учебных заведений. ПРОБЛЕМЫ ЭНЕРГЕТИКИ. 2017; Т.19. №5-6. С. 58-68.

7. Жуков Д.В., Чичерин С.В. Некоторые результаты проведения гидравлических испытаний на магистральных тепловых сетях города Омска // Известия высших учебных заведений. ПРОБЛЕМЫ ЭНЕРГЕТИКИ. 2017. Т. 19. №1-2. С. 15-22.

8. Тихомиров С.А., Василенко А.И. Проблемы перехода на закрытые системы теплоснабжения // Инженерный вестник Дона. 2013. Т. 27. №. 4.

9. Постников И.В, Стенников В.А. Обеспечение параметрической надежности теплоснабжающих систем // Известия высших учебных заведений. ПРОБЛЕМЫ ЭНЕРГЕТИКИ. 2017. Т. 19№ 3-4. С. 20-30.

10. Мухаметова Л.Р., Ахметова И.Г., Ахметов Т.Р. Оценка эффективности реализации программ энергосбережения. Проблемы энергосбережения в теплоснабжении // Известия высших учебных заведений. ПРОБЛЕМЫ ЭНЕРГЕТИКИ. 2015. № 9-10. С. 12-21.

11. Еремин А.В., Колесников С.В., Кудинов И.В., Бранфилева А.Н., Абишева Л.С. Математическая 
11. Eremin AV., Kolesnikov SV, Kudinov IV, Branfileva AN, Abisheva LS. Mathematical and computer model of heating network based on the electronic-hydraulic analogy. Power engineering: research, equipment, technology. 2017; 19(1-2):3-14. (In Russ). https://doi.org/10.30724/1998-9903-201719-1-2-3-14.

12. Varinov AA, Yakimov ND, Erashova YN. Engineering model of the thermal regime in detached house. Power engineering: research, equipment, technology.2016;(3-4):22-28.(InRuss). https://doi.org/10.30724/1998-9903-2016-0-3-4-2228.

13. Golub II, Voitov ON, Boloev EV, Semenova LV. Choice of short-term constant configuration of the distribution network. Power engineering: research, equipment, technology. 2018;20(9-10):39-51. (In Russ). https://doi.org/10.30724/1998-9903-2018-20-910-39-51.

14. Zvonareva JN, Van'kov JV. Work of system of heat supply at stage-by-stage introduction of the automated individual thermal points. Power engineering: research, equipment, technology. 2017; 19(1-2):31-40.(InRuss).

https://doi.org/10.30724/1998-9903-2017-19-1-2-3140.

15. Polovnikov VY. Numerical analysis of the influence of the design type of the channel of heat network on its thermal conditions and heat loss. Power engineering: research, equipment, technology. 2017; 19(5-6):79-88.(In

Russ) https://doi.org/10.30724/1998-9903-2017-19-5-6-7988.

16. Gazizov FN, Amosov NT. Prospective and problems of broad introduction of the closed scheme of HWS preparation in settlements of Russian Federation. 9 International school - seminar of young scientists and specialists "Energy saving - theory and practice”; 2018; Moscow, Russia. Moscow: MPEI Publishing House, 2018. (In Russ).

\section{Authors of the publication:}

Farit N. Gazizov - technical director of LLC "Neva Energy".

Irina G. Akhmetova - professor at Kazan State Power Engineering University. и компьютерная модель объединенной теплосети централизованного теплоснабжения // Известия высших учебных заведений. ПРОБЛЕМЫ ЭНЕРГЕТИКИ. 2017. Т.19. №1-2. С.3-14.

12. Варенов А.А., Якимов Н.Д., Ерашова Ю.Н. Инженерная модель теплового режима в индивидуальном доме // Известия высших учебных заведений. ПРОБЛЕМЫ ЭНЕРГЕТИКИ. 2016. №3-4. С.22-28.

13. Голуб И.И., Войтов О.Н., Болоев Е.В., Семенова Л.В. Выбор краткосрочной фиксированной конфигурации распределительной сети // Известия высших учебных заведений. ПРОБЛЕМЫ ЭНЕРГЕТИКИ. 2018. T. 20. № 9-10. С.39-51.

14. Звонарева Ю.Н., Ваньков Ю.В. Работа системы теплоснабжения при поэтапном внедрении автоматизированных индивидуальных тепловых пунктов // Известия высших учебных заведений. ПРОБЛЕМЫ ЭНЕРГЕТИКИ. 2017. Т. 19. №1-2. C.31-40.

15. Половников В.Ю. Численный анализ влияния вида конструкций канальной тепловой сети на ее тепловые режимы и тепловые потери // Известия высших учебных заведений. ПРОБЛЕМЫ ЭНЕРГЕТИКИ. 2017. Т.19. №5-6. С.79-88.

16. Газизов Ф.Н., Амосов Н.Т. Перспективы и проблематика широкого внедрения закрытой схемы приготовления ГВС в населенных пунктах Российской Федерации // труды 9 Международной школы - семинара молодых ученых и специалистов «Энергосбережение - теория и практика»; 2018 г., Москва. М.: Издательский дом МЭИ, 2018.

\section{Received}

March 05, 2019 